\title{
Improving the Productivity of Degraded Pasture Land Through Legume Forages over Sowing
}

\author{
Tesfay Atsbha ${ }^{2}$, Awet Estifanos ${ }^{1}$, Temesgen Tesfay ${ }^{2}$, Solomon Wayu ${ }^{2}$, Adhanom Baraki ${ }^{2}$ \\ ${ }^{1}$ Tigrai Agricultural Research Institute, Mekele Agricultural Research Center, Mekele, Ethiopia \\ ${ }^{2}$ Tigrai Agricultural Research Institute, Alamata Agricultural Research Center, Alamata, Ethiopia
}

Email address:

aweyetir@yahoo.com (A. Estifanos)

\section{To cite this article:}

Tesfay Atsbha, Awet Estifanos, Temesgen Tesfay, Solomon Wayu, Adhanom Baraki. Improving the Productivity of Degraded Pasture Land Through Legume Forages over Sowing. International Journal of Science, Technology and Society. Vol. 5, No. 3, 2017, pp. 33-36. doi: $10.11648 /$ j.ijsts.20170503.11

Received: March 3, 2017; Accepted: March 13, 2017; Published: May 17, 2017

\begin{abstract}
The experiment was undertaken for one season in Northern Ethiopia, at Emba Alaje District, Ayba Peasant Association to evaluate forage yield of the natural pasture over sown with three adapted legume forages. The design was Randomized Complete Block Design replicated three times. The treatments were control, Vicia dayscarpa, Vicia sativa and alfalfa (Hairy peruvian). The size of experimental plots were $100 \mathrm{~m}^{2}(10 \mathrm{~m}$ x $10 \mathrm{~m})$ each. Partial Budget Analysis, Dominance Analysis and Marginal Rate of Return were calculated to compare treatments economic benefits. Over sowing legume forages increased Dry Matter Yield significantly as compared with the control pasture land. The higher yield was recorded for pasture land over sown with Vicia sativa (3.96 t/ha) and Vicia dayscarpa $(3.12 \mathrm{t} / \mathrm{ha})$. The relative proportion of grass and legumes reached highest and significant by over sowing. However, pasture productivity of land over sown with Vicia sativa and Vicia dayscarpa were not significant for both grass and legumes. The species composition of treatments in the experimental site (Vicia sativa, Vicia dayscarpa and Hairy Peruvian) was 39.3, 33.3 and 7.3\%, respectively. It is therefore concluded that over sowing degraded grazing lands with Vicia sativa improves biomass yield, and it is also economical as compared with other treatments. This implies that for every one \$ addition cost of biomass yield production there is $\$ 0.44(44 \%)$ return by applying Vicia sativa.
\end{abstract}

Keywords: Botanical Composition, Dry Matter Yield, Natural Pasture and Vicia

\section{Introduction}

Livestock production is an integral part of the croplivestock systems of the Ethiopian agriculture. It is a source of draught power, manure and transport to support the crop sector. It is also a source of cash, nutrition and asset for the rural communities. Livestock is considered as a mobile bank that could be hired, shared, inherited and contracted by rural households. Livestock feed in the country is based on natural pastures, fallow grazing, stubble grazing and crop residues. The natural pasture resource consists of a wide range of grasses, legumes and other herbaceous species. More than $90 \%$ of the livestock feed in Ethiopia come from crop residues and natural pasture [1] out of which $37-43 \%$ estimated to be from private grazing land as in the case of Southern Ethiopia [2].
Legumes provide many benefits to a pasture system. Legumes do not need any nitrogen fertilization. They improve the seasonal distribution of forage dry matter by boosting summer production and they improve protein levels and overall digestibility of the forage. If a pasture mainly composes of unproductive native grasses, there may be a benefit of introducing improved grass species and varieties [3]. Over sowing is the simplest among forage development strategies and can be undertaken at very low cost. It involves broadcasting or sowing improved forage species into common grazing lands, native pastures and degraded areas without any cultivation or other inputs. Moreover, among the Tigray highland system the southern zone is home to the well- known Raya cattle breed. The breed is large-frame and one of the best indigenous milk animals in the country. It is also known for its meat production and draft power.

Although the contribution of livestock to support the crop 
production sector has been recognized as crucial, its productivity in Ethiopia is declining to a level that may affect the sustainability of synergism between the crop and livestock sectors [4]. Natural pasture and crop residues are poor in quality and provide inadequate protein, energy, vitamins and minerals [5]. Thus, the existing feed resources do not meet the nutrient requirements for growth and reproduction of animals. It is therefore one of the major constraints to livestock productivity. Although the study area has high potential contribution to the smallholder's livestock production, poor productivity of the grazing lands both in quality and quantity of the grazing resource poses a great problem in livestock farming of the Tigrai Regional State. This problem necessarily calls for improving the productivity of the grazing lands in the region. The objective of this study is therefore to test the potential of adapted legume species for over sowing and investigate their role in improving the productivity of degraded natural pasture land.

\section{Materials and Methods}

\subsection{Study Area}

The study was conducted at the highland of Northern Ethiopia, Southern Zone of Tigray, Emba Alaje District, Ayba Peasant Association. The elevation of the area is $2350 \mathrm{~m}$ with annual average rainfall of $912 \mathrm{~mm}$ and mean daily temperature ranging between $9-23^{\circ} \mathrm{C}$. The rainfall pattern is bi-modal with the belg rain (short rains) occurring March to May and the meher, which is the main season, rain lasting from June to September. Major crops such as sorghum (Sorghum bicolor), Teff (Eragrostis teff), Maize (Zea mays), wheat (Triticum spp.), barley (Hordeum vulgare L.), Faba bean (Vicia faba), field pea (Pisum sativum), linseed (Linum usitatissimum), onion (Allium cepa L.), pepper (Piper nigrum), cabbage (Brassica oleracea), fruits are grown in the study area [6]. Natural pasture is the major feed source in the area.

\subsection{Site Selection and Management}

A relatively flat field with less slop gradient variability was selected and demarcated before the execution of the experiment. The site was selected carefully to maintain its uniformity with regard to previous grazing pressure and soil type when visually observed. The treatment varieties were selected based on previous adaptability to the area and potential to enrich the quality of the forage herbage. The seeds were checked for its quality and germination. The seeding rate was $30 \mathrm{~kg} / \mathrm{ha}$ and $10 \mathrm{~kg} / \mathrm{ha}$ for vetch and alfalfa, respectively. Over sowing was performed on the onset of the main season rain. The plots were managed for three months which is the rainy period. After sowing the plots were left to grow naturally without any intervention except protection from external disturbances such as human and animal interference.

\subsection{Study Design}

The study design was Randomized Complete Block Design (RCBD). Each treatment was replicated three times. The treatments for the study were control, Vicia Sativa, Vicia dayscarpa and alfalfa (Hairy peruvian). Treatments were assigned randomly to each plot. All the treatments except the control were over sown broadcast with zero tillage without disturbing the excising plant and soil structure. The size of experimental plot was $100 \mathrm{~m}^{2}(10 \mathrm{~m} \times 10 \mathrm{~m})$. The spacing between plots vetch and alfalfa were 30 and $20 \mathrm{~cm}$, respectively. The spacing between blocks was $1 \mathrm{~m}$. The total experimental surface area occupied 1,376 $\mathrm{m}^{2}$ (32 m x $\left.43 \mathrm{~m}\right)$.

\subsection{Sampling Procedure}

The vegetation from each treatment was sampled using a quadrat of $0.25 \mathrm{~m}^{2}\left(\begin{array}{lllll}0.5 & \mathrm{~m} & \mathrm{x} & 0.5 \mathrm{~m}) & \text { size during a }\end{array}\right.$ predetermined sampling period. The quadrat was thrown randomly 5 times per plot. The biomass was harvested with a sickle at a height of approximately $10 \mathrm{~cm}$ above ground. Forage samples were weighed immediately. The average weight of the 5 harvests per plot was used for determination of pasture yield and quality. Harvested forage samples from each plot was weighed, labeled and air dried under the shade. The Dry Matter Yield (DMY) of each plot was converted to tons per hectare after drying.

\subsection{Botanical Composition}

Sub-samples representing $10 \%$ of the whole forage samples harvested from the treatments were taken for determination of Dry Matter Yield. For determination of botanical composition quadrat samples were harvested at the end of the experimental day and samples were weighed immediately and hand-sorted into botanical components of grasses, legumes and other species. Identification of species was undertaken in situ by using an illustrated field guide [7] for grasses and legumes. The relative proportion of botanical composition of the grasses, legumes and other herbage species in the treatment plots was determined by relating the weights of each species group to the weight of the whole sample.

\subsection{Partial Budget Analysis}

Partial Budget Analysis, Dominance Analysis and Marginal Rate of Return were calculated to determine the profitability of over sowing legume forages [8]. The economic analysis included the variable costs and benefits for the calculation. The gross field benefit per day was calculated by dividing the final sell of the biomass. Net Return (NR) or net benefit was calculated as the amount of money left when Total Variable Costs (TVC) are subtracted from total returns or Gross Field Benefit (TR). The cost was calculated based on cost needed for the different activities and in puts used for the application. Although the cost of harvesting and transporting matured hay is a variable cost, it was not included in the calculation. It is assumed that those 
costs are equal price for all treatments. However, the price of one tone of hay was estimated to be $\$ 48.1$ as a flat rate [9]. This is due to the quality difference in the different treatments is less appreciated and not yet estimated by the farmers of the area.

The dominance analysis or the change in net income $(\Delta \mathrm{NR})$ was computed as the difference between the change in total return $(\Delta \mathrm{TR})$ and the change in total variable costs from the control $(\triangle \mathrm{TVC})$ :

$$
\Delta \mathrm{NR}=\Delta \mathrm{TR}-\Delta \mathrm{TVC}
$$

The Marginal Rate of Return (MRR), which measures the increase in net income $(\Delta \mathrm{NI})$ in relation with each additional unit of expenditure $(\triangle T V C)$ normally expressed as a percentage:

$$
\mathrm{MRR}=\Delta \mathrm{NR} / \Delta \mathrm{TVC}
$$

\subsection{Statistical Analyses}

The data obtained from the experiment was subjected to Analysis of Variance using the General Linear Model
Procedure of SAS [10]. The significance of differences in yield between treatments was assessed by Tukey protected $\operatorname{LSD}(p=0.05)$.

\section{Results and Discussion}

\subsection{Dry Matter Yield}

The annual dry matter yield of the natural pasture was significantly affected by legume over sowing (Table 1). The higher yield was recorded on pasture land over sown with Vicia sativa (3.96 ton/ha) and Vicia dayscarpa (3.12 ton/ha). The result was similar with [11], in Zimbabwe, observed increased dry matter production of a natural pasture over sown with Disodium uncinatum (Silver leaf desmodium). Other authors have reported increased in pasture production when suitable pasture legumes were successfully incorporated [12]; [13] and [14]. Other benefits of over sowing pasture lands with legume species is the improvement of soil fertility through improved nitrogen fixation.

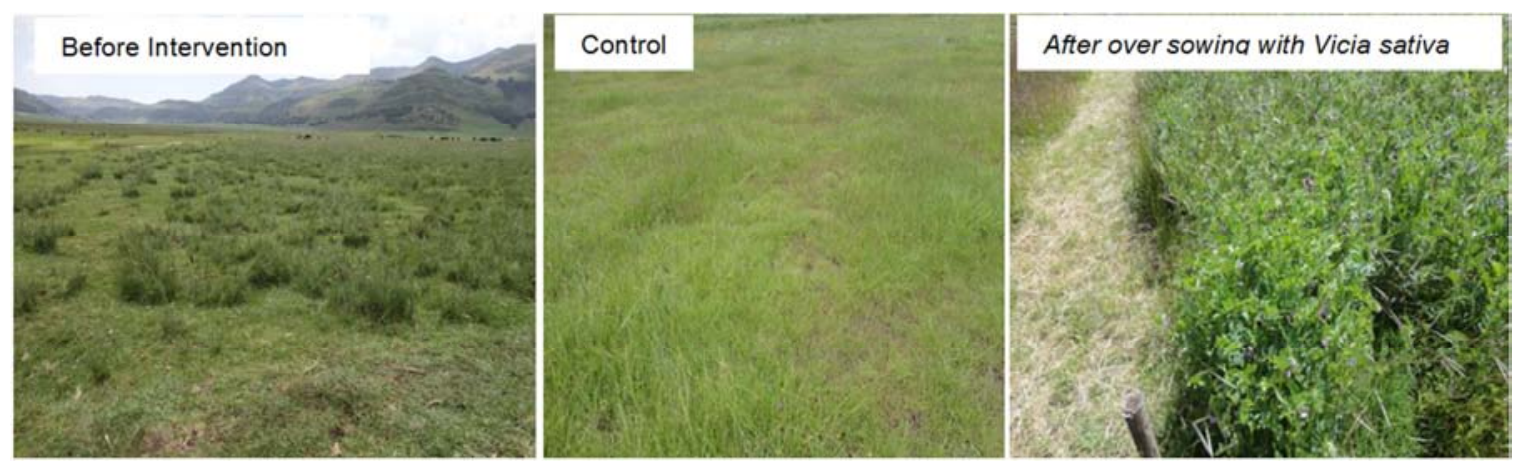

Figure 1. Comparison of before sowing, without sowing (fencing) and over sowing with Vicia sativa.

\subsection{Botanical Composition}

Natural pastures are composed of grasses, legumes, sedges and other heterogeneous plants in various families, which could be herbaceous or woody forms [15]. Pasture component species, grasses, sown legumes, existing legumes and others were significantly different among all the treatments and higher results of grass composition were obtained for untreated pasture $(85.5 \%)$, followed by Hairy peruvian sown pasture $(80.3 \%)$. This is due to the simple logic that the naturally existing plants are grass and the poor performance of the Hairy peruvian, respectively. However, pasture land sown with Vicia sativa and Vicia dayscarpa was similar for both grass and legumes composition. This is because both the varieties are from the same family.

The composition of treatments in the experimental site for Vicia sativa, Vicia dayscarpa and hairy Peruvian was 39.3\%, $33.3 \%$ and $7.3 \%$, respectively (Table 1). The lower composition of the hairy Peruvian alfalfa variety could be its adaptation to irrigated cultivation or relatively higher rainfall and lower temperatures [16] and the poor capacity of the small seeds to establish in zero tillage or over sowing.

\begin{tabular}{|c|c|c|c|c|c|c|c|}
\hline \multirow{2}{*}{ Treatments } & \multirow{2}{*}{ DMY } & \multicolumn{6}{|c|}{ Species composition } \\
\hline & & Grass & Natural Legume & Vicia sativa & Vicia dayscarpa & Hairy peruvian & Other species \\
\hline Control & $2.09^{\mathrm{a}}$ & $85.5^{\mathrm{a}}$ & $11.3^{\mathrm{a}}$ & - & - & - & $3.3^{\mathrm{a}}$ \\
\hline Vicia sativa & $3.96^{\mathrm{b}}$ & $53.3^{\mathrm{b}}$ & $10.4^{\mathrm{ab}}$ & 39.3 & - & - & $2^{\mathrm{b}}$ \\
\hline Vicia dasycarpa & $3.12^{\mathrm{b}}$ & $56.2^{\mathrm{b}}$ & $10.5^{\mathrm{ab}}$ & - & 33.3 & - & $3^{\mathrm{ab}}$ \\
\hline Hairy peruvian & $2.02^{\mathrm{a}}$ & $80.3^{\mathrm{a}}$ & $8.33^{\mathrm{b}}$ & - & - & 7.33 & $4^{\mathrm{a}}$ \\
\hline LSD & 1.37 & 6.22 & 2.76 & 3.60 & 4.72 & 2.51 & 1.28 \\
\hline SEM & 0.68 & 11.7 & 1.96 & 0.34 & 3.25 & 5.58 & 1.58 \\
\hline $\mathrm{p}$ & 0.07 & .0001 & 0.17 & 1 & .0001 & .0001 & 0.002 \\
\hline
\end{tabular}

Table 1. The effect of over sowing legume forages on DMY, grasses, legumes and other plant species composition.

ab Means in the same column without common letter are different; DMY- Dry Matter Yield; LSD: Least Significant Difference; SEM: Standard Error of Mean 


\subsection{Cost Benefit Analysis}

Although over sowing of Vicia sativa pasture had higher biomass yield, it is economical to use it for improving pasture land as compared with unsown legume forage pasture land. This means that for every one $\$$ addition cost of biomass yield production there is $\$ 0.44$ (44\%) return (Table 2 ). Although, over sowing of the natural pasture with the other legume species increased biomass production, it is not economical to apply these as degraded land improving legume species.

Table 2. Partial cost benefit analysis.

\begin{tabular}{|c|c|c|c|c|c|c|c|c|c|c|}
\hline Treatments & input $\$$ & $\begin{array}{l}\text { Labor } \\
\text { cost } \$\end{array}$ & TVC $\$$ & $\begin{array}{l}\text { yield } \\
\text { ton/ha }\end{array}$ & $\begin{array}{l}\text { Gross } \\
\text { income }\end{array}$ & $\begin{array}{l}\text { Total } \\
\text { return \$ }\end{array}$ & $\begin{array}{l}\text { Net } \\
\text { return \$ }\end{array}$ & $\Delta T V C \$$ & $\Delta \mathbf{N R}$ & $\begin{array}{l}\text { MRR } \\
\text { Ratio }\end{array}$ \\
\hline control & 0.00 & 0.00 & 0.00 & 2.09 & 202 & 202 & 202 & & & \\
\hline Vicia sativa & 45.0 & 50.0 & 95.0 & 3.96 & 396 & 346 & 251 & 95.0 & 42.0 & 0.44 \\
\hline Vicia dayscarpa & 45.0 & 50.0 & 95.0 & 3.12 & 312 & 262 & 167 & 95.0 & -42.0 & -0.44 \\
\hline Hairy peruvian & 250 & 50.0 & 300 & 2.02 & 202 & 152 & -148 & 300 & -357 & -1.19 \\
\hline
\end{tabular}

$\Delta \mathrm{NR}=$ change in net return; $\Delta \mathrm{TVC}=$ change in total variable cost $\mathrm{MRR}=$ Marginal Rate of Return

\section{Conclusion}

Over sowing natural pastures with adapted exotic legume species improved the DM yield and species composition than untreated natural pasture land. Over sowing adapted legume species for rehabilitation of degraded pasture land is one of the best solution to the grazing lands in the high lands of Ethiopia to improve the quality and quantity of natural pasture. Over sowing of Vicia sativa pasture had higher biomass yield and it is economical to use it for improving degraded pasture lands.

\section{References}

[1] T. Alemu and G. Lemma, Botanical composition and productivity of natural pasture in the Arjo Awraja, Western Ethiopia. In: Proceedings of the Fourth National Livestock Improvement Conference Held at Addis Ababa, 13-15 Nov., 1991, Pp. 205-210.

[2] N. Tegene, G. Dinku and B. Mohammed, Assessment of potential of natural pasture and other feed resources in sweet potato production system of Shebedino District, Sidama Zone, SNNPRS, Ethiopia. International Journal of Livestock Production, 2015, 6: 8-91-98.

[3] M. Alemayehu, Forage production in Ethiopia a case study with implications for livestock production: Ethiopian Society of Animal Production Addis Abeba, Ethiopia, 2002.

[4] A. Tilahun, M. Solomon and R. Ralph, Identification of Livestock Feed Production in Ethiopian Highlands: Potential and Experiences of the African Highlands Initiative. Presented at the 19 EVA Annual conference, 8 June 2005, ECA, Addis Ababa, 2005.

[5] K. Daniel, Effect of development stages of at harvest, nitrogen application and moisture availability on the yield and nutritional value of Rhodes grass (Chloris gayana) Lucerne (Medicago sativa) pastures (Doctoral Dissertation). Available from Swedish University of Agricultural Sciences, Uppsala, Sweden, 1990.
[6] T. Girmay, G. Girmay, G. Alem, G. Abrhaley, G. Yemane, and T. Hagos, Participatory Rural Appraisal Report: Alaje Woreda, Tigray Region, 2014.

[7] B. Froman, and S. Persson, An Illustrated Guide to the Grasses of Ethiopia. Chilalo Agricultural Development Unit. Assela, 1974.

[8] M. Upton, Farm Management in Africa: The Principle of Production and Planning. Oxford University Press, Great Britain, 1979, pp. 282-298.

[9] A. Tesfay, E. Awet, G., S. Wayu, T. Tesfay, and A. Baraki, Rehabilitation of degraded pasture land through application of urea and slurry: the case of Ayba pasture land, southern Tigray, Ethiopia, 2015, Livestock Research for Rural Development. Volume 27, Article \#186. Retrieved September 21, 2016, from http://www.lrrd.org/lrrd27/9/tesf27186.html

[10] SAS, Statistical Analysis Systems, Institute Inc., NC. U.S.A, 1998.

[11] J. N. Clatworthy, Effect of reinforcement of native grazing with Silver leaf desmodium (Desmodium uncinatum) on dry season performance of beef steers in Zimbabwe, 1984, Trop. Grassl. 18: 198-205.

[12] B. Walker, Effects of nitrogen fertilizer and forage legumes on Cenchrus ciliaris pasture in Western Tanzania East Afr. Agric. For. J. 38: 375-382, 1969.

[13] T. H. Stobbs, The effect of grazing management upon pasture productivity in Uganda. I. Stocking rate. Tropical Agric. (Trinidad), 1969, 46: 187-194.

[14] A. B. Lwoga, The potential of forage legumes in the exploitation of grazing resources in Tanzania. Paper presented at a symposium on the role of biology in the development and utilization of natural resources in Tanzania, Dare-Salaam, 1983.

[15] R. J. Mclllroy, An introduction to tropical grassland husbandry. Oxford University Press, London, 1972, P. 140.

[16] H. L. Westover, and H. M. Tysdal, Alfalfa varieties in the United States, US Department of Agriculture. Farmers' Bulletin no. 1731. Washington DC, 1945. 